\title{
The Influence of Gender and Special Education Training on Attitudes towards Inclusion
}

\section{Şenol Orakcı}

Teacher, Açıköğretim Ortaokulu, Turkey, senolorak@gmail.com

\section{Osman Aktan}

Teacher, Düzce Rehberlik ve Araştırma Merkezi, Turkey, karakteregitimi@gmail.com

\section{Çetin Toraman}

Teacher, Keçiören Rehberlik ve Araştırma Merkezi, Turkey, cetintoraman@gmail.com

\section{Hüseyin Çevik}

Teacher, Keçiören Tevfik Ünsal İlkokulu, Turkey, cevik1979@gmail.com

Inclusive education practices on special education are quite important and discussed intensively. Within this context, teachers' viewpoints and attitudes towards inclusive education practices are of great importance. There are many publications about special education practices in the literature review. In this article, it has been focused on inclusive education practices in special education and synthesizing the findings of studies examining teachers' attitudes towards special education. Teachers' attitudes towards inclusive education practices have been examined in terms of gender and special education training. There are 28 studies that met the criteria listed including the sample about the influence of the gender on the attitudes towards inclusive education and 23 studies meeting the inclusion criteria including the sample about the influence of special education training on teachers' or prospective teachers' attitudes. The findings of the study indicated that gender and special education training did not affect the attitudes towards inclusive education significantly. Of the moderating factors observed in the study, only the differences in teachers' branches were seen to be of significance.

Key Words: inclusion, attitude, meta-analysis, gender, training, special education

\section{INTRODUCTION}

Today, individual differences in the configuration of the education system are very important. It is necessary to provide appropriate conditions for individuals in terms of social, personal and educational needs in the education that individual differences are taken into account. Within this framework, inclusion is based on the assumption that students with special education needs can learn in normal education classes which are less restricting educational environment for them on a full-time or part-time basis 
providing them with necessary support services (Batu \& İftar, 2011). Inclusive education is an approach to serving children with disabilities within general education settings and it also supports and welcomes diversity among all the students, eliminating social exclusion as well as addressing their individual differences and needs (UNESCO, 2001).

Teacher attitudes are one of the major factors affecting the success of inclusive education (Martinez, 2003 and Sharma at al., 2006). Whereas positive attitudes towards inclusive educational practises and mainstreaming students affect educators' educational practices in a positive way, negative attitudes often reflect the students that need to get inclusive education in the educational environment in a manner of their open or hidden refusal to these inclusive educational practices (Avramidis \& Norwich, 2002).

Many studies attempting to determine the attitudes of teachers with or without inclusive education towards inclusive education practices have been done. In most of these studies, it has been concluded that having inclusive education courses led to positive changes in the attitudes of teachers or prospective teachers on inclusive education (Bender at al., 1995, Dickens \& Smith, 1995, Avissar, 2000, Avramidis at al., 2000, Temel, 2000, Sarı, 2002, Gözün \& Yıkmış, 2003, Sarı Bozgeyikli, 2003, Burke \& Sutherland, 2004, Parasuram, 2006, Babaoğlan \& Y1lmaz, 2010, Cankaya, 2010 and Orel at al., 2004). On the other hand, some researchers found that there was no significant difference in teachers' attitudes in terms of special education training (Leyser \& Tappendorf, 2001 and Cagney, 2009). As for the studies teachers' attitudes in relation to gender, some studies have been done about teachers' attitudes in relation to gender. One study conducted by Leyser and Tappendorf (2001) on teachers' attitudes towards inclusion revealed that female teachers had significantly higher scores than males on what was referred to as "The Social Growth Factor", showing a more positive attitude toward the social aspects of inclusion. Alver (2011) also found a similar result in favor of female prospective teachers. However, other researchers found that there was no statistically significant difference between teachers' attitudes towards inclusion in terms of gender (Bek at al., 2009, Cagney, 2009, Seçer, 2011 and Çolak \& Çetin, 2014).

There is a strong need for meta-analyses which may be defined as an analysis of empirical studies conducted on a given topic or in similar fields that include the grouping of the studies in accordance with specific criteria and the combination of quantitative findings related to these studies to synthesize the results of all these studies and to develop a new direction for the following studies on teachers' attitudes towards special education (Dinçer, 2014 and Erkuş, 2013). Within the context of this study, it has been aimed to examine the effect size for teachers' attitudes towards special education and whether there are any differences in terms of the effective sizes.

\section{The Purpose of the Study}

In this study, there was an attempt to arrive at a synthesis of studies hitherto conducted on the subject of the influence of gender and special education training on attitudes towards inclusion. In this context, the hypotheses below were tested: 
1. There is a significant difference between the attitudes of teachers and prospective teachers receiving special education training and the prospective teachers or teachers receiving no special education training.

2. There is a significant difference between the attitudes of male and female teachers towards inclusive education.

3. Being a prospective teacher or teacher, the branch of teacher, level of education and the type of publication are meaningful moderators.

\section{METHOD}

This study was carried out to arrive at a synthesis of studies hitherto conducted on the subject of the influence of gender and special education training on attitudes towards inclusion employing a meta-analysis method.

\section{Data Collection}

The studies included within the research were all taken from the "ProQuest Citations", EBSCO, Higher Academic Council (YÖK) and "National Thesis Search System", ERIC, and ScienceDirect databases from January 2005 to December, 2015 by using key words such as education inclusion, inclusive education, mainstreaming and attitude. The first stage when employing the meta-analysis method on academic studies already conducted with regards to the purposes of one's own research is to clearly define the criteria of selection for the studies to be included for that purpose. The criteria and factors on whether studies should be incorporated within the research are listed below:

(I) Time interval of the studies to be included in meta-analysis: Studies must be conducted between the years of 2005-2015. (II) Published and unpublished resources: Master's theses and doctoral dissertations, periodical academic journals, electronic academic journals, databases, proceedings of conferences and symposia. (III) Appropriateness of the research design used in the studies. (IV) The use of instructional method that fits the research aim. ( $V$ ) To have the clarity of arithmetical averages, standard deviations and numbers of participants.

\section{Data Analysis}

The data obtained from the studies that met the criteria defined above were all loaded into the "Comprehensive Meta Analysis (CMA)" software program. In the studies of metaanalysis, the effect size as its basic unit of measurement/evaluation is employed (Borenstein at al., 2009). "What method was used to calculate the effect size?" is the most important question in this instance. These are: the fixed effect(s) model and the random effect(s) model. In the fixed effect model, the most important assumption is that "for all studies included in the meta-analysis there exists only one actual effect size" (Borenstein at al., 2009) whereas the random effect model is based on the principle that "the real effect size of factors such as the age of participants, the educational level of participants or the size of the class may differ from study to study" (Üstün \& Eryllmaz, 2014). As a result of Q notation, the critical value (p) should be found to fall below the critical values, then this result may be interpreted in such a way that "all studies do not share the general values". In such a situation, there exists heterogeneity between the studies (Borenstein at al., 2009 and Hedges $\&$ Olkin, 1985). The $\mathrm{I}^{2}$ statistical value provides information regarding the degree of this variation. In this study, there existed heterogeneity between the studies. Therefore, the average effect size was calculated according to the random effect model. 
The publication bias of the studies included in the research is then analyzed using a funnel plot. In situations, in which there exists no publication bias, symmetry should be observed. Furthermore, the accumulation of elements on the internal and upper parts of the graph demonstrates that the contribution of the effect size is high (Cooper at al., 2009).

Moderating analysis is a method of analysis that provides information for the testing of differences between the average effect sizes of moderating factors and the type of differences between sub-groups (Littel at al., 2008). The statistical significance in the difference between moderating factors are tested using the $\mathrm{Q}$ statistical method developed by Hedge and Olkin (1985). In this method the Q statistical measure is divided into two as $\mathrm{Q}_{\text {between }}\left(\mathrm{Q}_{\mathrm{b}}\right)$ and $\mathrm{Q}_{\text {within }}\left(\mathrm{Q}_{\mathrm{w}}\right)$; the analysis is then carried out using these two $\mathrm{Q}$ figures. While $\mathrm{Q}_{\mathrm{w}}$ is used to test the homogeneity (Uniformity) within the moderating factor itself, $\mathrm{Q}_{\mathrm{b}}$ is used to test the homogeneity between the groups (Borenstein at al., 2009 and Hedges \& Olkin, 1985). In this study, the differences between the moderating factors were observed using the value $\mathrm{Q}_{\mathrm{b}}$. Four moderating factors were defined as being thought to exert an important effect on the effect size. These were participant, the branch, the level of education and the type of publication.

\section{FINDINGS}

The research was based on the main topic of influence of gender and special education training on attitudes towards inclusion. The general breakdowns of the studies accepted for the meta-analysis are displayed in Table 1 and 2 .

Table 1: Information concerning the studies included for research with regard to the influence of gender on attitudes towards inclusive education

\begin{tabular}{|c|c|c|c|c|c|}
\hline $\begin{array}{l}\text { Moderating } \\
\text { Factors }\end{array}$ & $\begin{array}{l}\text { Degree of Moderating } \\
\text { Factor }\end{array}$ & $n$ & $\begin{array}{l}\text { Moderating } \\
\text { Factors }\end{array}$ & $\begin{array}{l}\text { Degree of Moderating } \\
\text { Factor } \\
\end{array}$ & $n$ \\
\hline \multirow{3}{*}{ Participant } & Teacher & 24 & \multirow{6}{*}{ Branch } & Pre-school & 2 \\
\hline & Prospective Teacher & 4 & & Special Education & 4 \\
\hline & Total & 28 & & $\begin{array}{l}\text { Guidance } \\
\text { Councelling }\end{array}$ & 2 \\
\hline \multirow{5}{*}{$\begin{array}{l}\text { Level of } \\
\text { education }\end{array}$} & Primary & 19 & & Classroom & 14 \\
\hline & High School & 2 & & Unspecified & 6 \\
\hline & Higher Education & 4 & & Total & 28 \\
\hline & Unspecified & 3 & \multirow{11}{*}{ Year } & 2005 & 1 \\
\hline & Total & 28 & & 2006 & 1 \\
\hline \multirow{13}{*}{ Country } & The USA & 1 & & 2007 & 1 \\
\hline & BAE & 1 & & 2008 & 2 \\
\hline & Bostwana & 1 & & 2009 & 5 \\
\hline & India & 2 & & 2010 & 3 \\
\hline & Scotland & 1 & & 2011 & 3 \\
\hline & Canada & 1 & & 2012 & 3 \\
\hline & Kenya & 1 & & 2013 & 4 \\
\hline & Kuwait & 1 & & 2014 & 5 \\
\hline & Nigeria & 1 & & Total & 28 \\
\hline & Saudi Arabia & 4 & \multirow{4}{*}{$\begin{array}{l}\text { Publication } \\
\text { Type }\end{array}$} & Article & 14 \\
\hline & Turkey & 13 & & Master Thesis & 11 \\
\hline & Greece & 1 & & Doctoral Thesis & 3 \\
\hline & Total & 28 & & Total & 28 \\
\hline
\end{tabular}


In accordance with the criteria 28 studies on the subject of the influence of gender on attitudes towards inclusive education, as can be seen in table 1, were chosen. The studies were conducted predominantly on teachers composed of classroom teachers, in primary level and were carried out between 2009 and 2014. Moreover, these studies mainly consisted of master theses and scientific articles.

Table 2: Information concerning the studies included for research with regard to the influence of special education training on attitudes towards inclusive education

\begin{tabular}{llc}
\hline $\begin{array}{l}\text { Moderating } \\
\text { Factors }\end{array}$ & $\begin{array}{l}\text { Degree of Moderating } \\
\text { Factor }\end{array}$ & $n$ \\
\hline \multirow{4}{*}{ Participant } & Teacher & 20 \\
& Prospective Teacher & 3 \\
& Total & 23 \\
\hline & Primary & 18 \\
Level of & High School & 2 \\
education & Higher Education & \\
& Total & 3 \\
& The USA & 23 \\
\hline \multirow{4}{*}{ Country } & BAE & 1 \\
& Bostwana & 1 \\
& India & 1 \\
& Scotland & 1 \\
& Canada & 1 \\
& Kenya & 1 \\
& Kuwait & 1 \\
& Nigeria & 1 \\
& Saudi Arabia & 1 \\
& Turkey & 12 \\
& Greece & 23 \\
\hline \multirow{4}{*}{ Total } &
\end{tabular}

\begin{tabular}{|c|c|c|}
\hline $\begin{array}{l}\text { Moderating } \\
\text { Factors }\end{array}$ & $\begin{array}{l}\text { Degree of Moderating } \\
\text { Factor }\end{array}$ & $n$ \\
\hline \multirow{8}{*}{ Branch } & Pre-school & 4 \\
\hline & Special Education & 1 \\
\hline & Guidance & \\
\hline & Councelling & 1 \\
\hline & Classroom & 12 \\
\hline & Branch & 3 \\
\hline & Unspecified & 2 \\
\hline & Total & 23 \\
\hline \multirow{11}{*}{ Year } & 2005 & 1 \\
\hline & 2006 & 1 \\
\hline & 2007 & 2 \\
\hline & 2008 & 2 \\
\hline & 2009 & 3 \\
\hline & 2010 & 5 \\
\hline & 2011 & 3 \\
\hline & 2012 & 1 \\
\hline & 2013 & 3 \\
\hline & 2014 & 2 \\
\hline & Total & 23 \\
\hline \multirow{4}{*}{$\begin{array}{l}\text { Publication } \\
\text { Type }\end{array}$} & Article & 11 \\
\hline & Master Thesis & 11 \\
\hline & Doctoral Thesis & 1 \\
\hline & Total & 23 \\
\hline
\end{tabular}

As it is seen in table 2, in accordance with the criteria 23 studies on the subject of the influence of special education training on attitudes towards inclusive education were chosen. The studies were conducted predominantly on teachers composed of classroom teachers, in primary level and were carried out in 2010 and in Turkey. These studies also mainly consisted of master theses and scientific articles.

As for the size of the sample being reached through meta-analysis of studies, the number of female is 3.854 and male is 2.966 , the number of individuals with training is 1.501 and without training is 2.568 .

Findings on the influence of gender and special education training on attitude towards inclusive education

Before calculation of the effect size for gender and special education training in the study, it was found that 27 studies were $\left(\mathrm{Q}_{(27)}=247,884, \mathrm{p}<.05\right)$ heterogeneous in terms of gender and 22 studies were found to be heterogeneous $(\mathrm{Q}(22)=270,345, \mathrm{p}<.05)$ in terms of special education training. As a result of the analyses conducted, it was determined that the $\mathrm{Q}$ value was significant and so it confirmed the assumption that the studies differed from one another. The degree of heterogeneity for gender was found to be $89 \%$. $\left(\mathrm{I}^{2}=\% 89,108\right)$ and 
the degree of differentiation for special education training was found to be $91 \%\left(\mathrm{I}^{2}=\right.$ $\% 91,862$ ). According to Cooper at al. (2009), in cases where the $\mathrm{I}^{2}$ value exceeds $75 \%$, this means that the studies under observation are heterogeneous to a high degree. In cases where studies are found to be heterogeneous, the random effect model is seen to provide more effective results regarding calculation of the common effect size in meta-analysis calculations. The results of the meta-analysis carried out in accordance with the random effect model are summarized in Table 3.

Table 3: Findings Concerning the Effect Size of the Meta-Analysis Conducted According to the Random Effect Model.

\begin{tabular}{ccccccc}
\hline \multirow{2}{*}{$\begin{array}{c}\text { Number of Studies } \\
(N)\end{array}$} & $\begin{array}{c}\text { Size Effect } \\
(\text { ES })\end{array}$ & $\begin{array}{c}\text { Standard } \\
\text { Error }\end{array}$ & $Z$ & \multicolumn{2}{c}{$\begin{array}{c}\text { With a confidence interval of } \\
\text { 95\% }\end{array}$} \\
\hline Gender & 28 & 0,034 & 0,081 & 0,193 & $-0,124$ & Lower limit \\
\hline Traning & 23 & $-0,016$ & 0,131 & $-0,125$ & $-0,274$ & 0,193 \\
\hline
\end{tabular}

As it is seen in table 4 with regards to the results of the analyses that were conducted in accordance with the random effect model, the value of the size effect for gender was not found to be significant $(Z=0,193, p>.01)$ with a confidence interval of $95 \%$ and the value of the size effect for special education training was not found to be significant $(\mathrm{Z}=$ $-0,125, p>.01)$ with a confidence interval of $95 \%$. The value of the average size effect for gender was 0.034 and found to be positive and for special education training on attitudes towards inclusive education was $-0,016$ and found to be negative. Both of them were determined not to be significantly effect size. Therefore, it can be said that having a special education training or not and to be a male or female does not affect significantly attitude towards inclusive education.

The degree to which publication bias is present in terms of gender and special education training may be examined through the use of a funnel plot (graph). The graphs that highlight the publication bias presented in this study are shown in Figure 1.

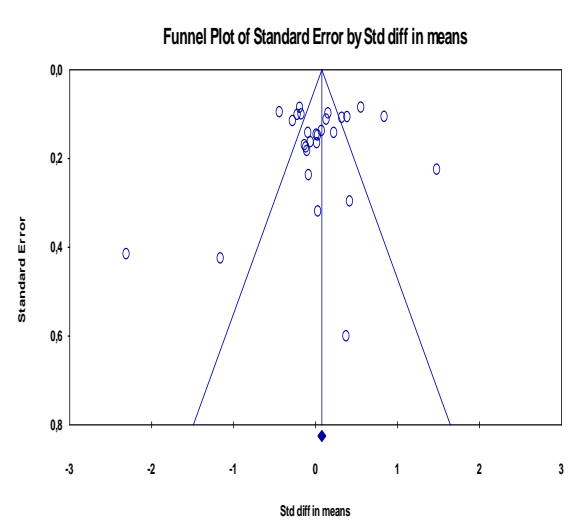

Influence of special education training

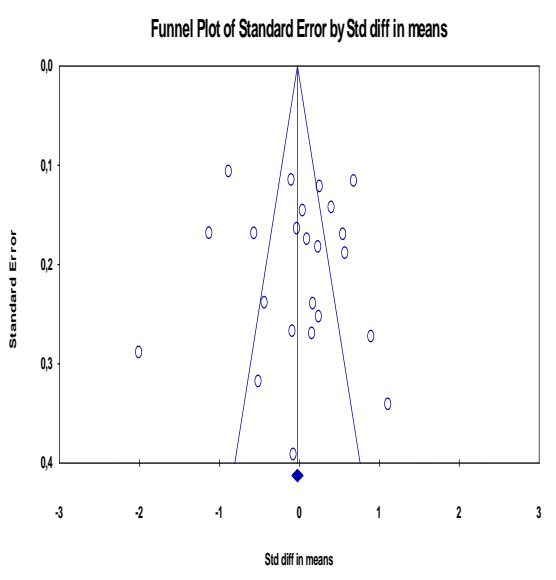

Influence of gender

Figure 1. Funnel Plot Demonstrating the Degree of Publication Bias. 
As it is seen in figure 1, the great majority of the studies included in the research are not collected in the upper and internal part of the graph. Furthermore, the graph is not symmetrical on both sides. Distortion or a break in the symmetry represents an indication of publication bias. So as to ascertain how many studies break the inherent symmetry, the Duval and Tweeddie Method was employed. According to this method, so as to ensure the symmetry, 7 studies for gender and 5 studies for special education training needed to be moved to the right side of the graph for special education training. After carrying out this alteration, the effect size for gender is calculated at 0.209 and the effect size for special education training is calculated at $-0,226$.

Among all the studies including this research, the studies of Tekneci (2010), Prakash (2012), Fakolade (2009), Dukmak (2013) and Chopra (2008) increased the degree of heterogeneity/differentiation most in terms of gender. The studies of Boyle et al (2013), Chopra (2008), Özdemir (2010), Yiğiter (2005), Subban and Sharma (2006), Cankaya (2010), Kalyva et al (2007), Almotairi (2013) and Kuzu (2011) increased the degree of heterogeneity/differentiation most in terms of gender.

The influence of gender and special education training on attitudes towards inclusion- Moderating Factors

The studies investigating the influence of gender and special education training on attitudes towards inclusion have been analyzed to determine whether or not there exists a difference in terms of branch, level of education, and type of publication. The results are shown in Table 4 and 5.

\begin{tabular}{|c|c|c|c|c|c|c|c|c|c|}
\hline \multirow{2}{*}{$\begin{array}{l}\text { Moderating } \\
\text { Factors }\end{array}$} & \multirow{2}{*}{$\begin{array}{l}\text { Degree of } \\
\text { Moderating } \\
\text { Factor }\end{array}$} & \multirow[t]{2}{*}{$N$} & \multirow[t]{2}{*}{$E B$} & \multirow[t]{2}{*}{$S_{\text {hata }}$} & \multirow[t]{2}{*}{$Z$} & \multicolumn{2}{|c|}{$\begin{array}{c}\text { Effect Size with } \\
\text { Confidence } \\
\text { Interval of } 95 \%\end{array}$} & \multirow{2}{*}{$\begin{array}{c}Q_{\text {between }} \\
\left(Q_{b}\right)\end{array}$} & \multirow[t]{2}{*}{$s d$} \\
\hline & & & & & & $\begin{array}{l}\text { Lower } \\
\text { Limit } \\
\end{array}$ & $\begin{array}{l}\text { Upper } \\
\text { limit }\end{array}$ & & \\
\hline \multirow{2}{*}{ Participant } & Teacher & 24 & $\overline{-}, 000$ & 0,085 & $-0,003$ & $-0,167$ & 0,166 & \multirow{2}{*}{0,864} & \multirow{2}{*}{1} \\
\hline & $\begin{array}{l}\text { Prospective } \\
\text { Teacher }\end{array}$ & 4 & 0,228 & 0,231 & 0,990 & $-0,224$ & 0,681 & & \\
\hline \multirow{5}{*}{ Branch } & Pre-school & 2 & 0,827 & 0,105 & $7,867 * * *$ & 0,621 & 1,033 & \multirow{5}{*}{$44,097 * * *$} & \multirow{5}{*}{4} \\
\hline & $\begin{array}{l}\text { Special } \\
\text { Education }\end{array}$ & 4 & 0,014 & 0,117 & 0,118 & $-0,215$ & 0,243 & & \\
\hline & $\begin{array}{l}\text { Guidance and } \\
\text { Councelling }\end{array}$ & 2 & 0,094 & 0,102 & 0,920 & $-0,106$ & 0,294 & & \\
\hline & Classroom & 14 & $\overline{0}, 017$ & 0,132 & $-0,127$ & $-0,276$ & 0,242 & & \\
\hline & Branch & 6 & $\begin{array}{l}- \\
0,028\end{array}$ & 0,145 & $-0,191$ & $-0,312$ & 0,257 & & \\
\hline \multirow{4}{*}{$\begin{array}{l}\text { Level of } \\
\text { education }\end{array}$} & Primary & 19 & $\overline{0}, 018$ & 0,098 & $-0,186$ & $-0,211$ & 0,174 & \multirow{4}{*}{7,523} & \multirow{4}{*}{3} \\
\hline & High School & 2 & 0,336 & 0,102 & $3,282 * * *$ & 0,135 & 0,536 & & \\
\hline & $\begin{array}{l}\text { Higher } \\
\text { Education }\end{array}$ & 4 & 0,228 & 0,231 & 0,990 & $-0,224$ & 0,681 & & \\
\hline & Unspecified & 3 & $\overline{0}, 170$ & 0,292 & $-0,583$ & $-0,744$ & 0,403 & & \\
\hline $\begin{array}{l}\text { Type of } \\
\text { publication }\end{array}$ & Article & 14 & $\begin{array}{l}- \\
0,004\end{array}$ & 0,118 & $-0,034$ & $-0,235$ & 0,227 & 0,460 & 2 \\
\hline
\end{tabular}




$\begin{array}{lccccrr}\text { Master Thesis } & 11 & 0,041 & 0,138 & 0,294 & -0,230 & 0,311 \\ \begin{array}{l}\text { Doctoral } \\ \text { Thesis }\end{array} & 3 & 0,176 & 0,238 & 0,737 & -0,291 & 0,642\end{array}$

Table 5: The influence of special education training on attitudes towards inclusive education with regard to moderating factors

\begin{tabular}{|c|c|c|c|c|c|c|c|c|c|}
\hline \multirow{2}{*}{$\begin{array}{l}\text { Moderating } \\
\text { Factors }\end{array}$} & \multirow{2}{*}{$\begin{array}{l}\text { Degree of } \\
\text { Moderating } \\
\text { Factor }\end{array}$} & \multirow[t]{2}{*}{$N$} & \multirow[t]{2}{*}{$E B$} & \multirow[t]{2}{*}{$S_{\text {hata }}$} & \multirow[t]{2}{*}{$Z$} & \multicolumn{2}{|c|}{$\begin{array}{c}\text { Effect Size with } \\
\text { Confidence } \\
\text { Interval of } 95 \%\end{array}$} & \multirow{2}{*}{$\begin{array}{c}Q_{\text {between }} \\
\left(Q_{b}\right)\end{array}$} & \multirow[t]{2}{*}{$s d$} \\
\hline & & & & & & $\begin{array}{l}\text { Lower } \\
\text { Limit }\end{array}$ & $\begin{array}{l}\text { Upper } \\
\text { limit }\end{array}$ & & \\
\hline \multirow{2}{*}{ Participant } & Teacher & 20 & 0,027 & $\begin{array}{l}0,13 \\
1\end{array}$ & 0,207 & $-0,229$ & 0,284 & \multirow{2}{*}{0,712} & \multirow{2}{*}{1} \\
\hline & $\begin{array}{l}\text { Prospective } \\
\text { Teacher }\end{array}$ & 3 & - & $\begin{array}{l}0,36 \\
7 \\
\end{array}$ & $-0,822$ & $-1,022$ & 0,418 & & \\
\hline \multirow{6}{*}{ Branch } & Pre-school & 4 & 0,131 & $\begin{array}{l}0,28 \\
0\end{array}$ & 0,469 & $-0,417$ & 0,680 & \multirow{6}{*}{$\begin{array}{c}114,241 * * \\
*\end{array}$} & \multirow{6}{*}{5} \\
\hline & $\begin{array}{l}\text { Special } \\
\text { Education }\end{array}$ & 1 & $\begin{array}{l}- \\
0,434\end{array}$ & $\begin{array}{l}0,23 \\
9\end{array}$ & $-1,818$ & $-0,902$ & 0,034 & & \\
\hline & $\begin{array}{l}\text { Guidance } \\
\text { and } \\
\text { Councelling }\end{array}$ & 1 & $\overline{-}, 434$ & $\begin{array}{l}0,23 \\
9\end{array}$ & $-1,818$ & $-0,902$ & 0,034 & & \\
\hline & Classroom & 12 & $\begin{array}{l}- \\
0,071\end{array}$ & $\begin{array}{l}0,18 \\
2\end{array}$ & $-0,391$ & $-0,427$ & 0,285 & & \\
\hline & Branch & 3 & $-\overline{0,042}$ & $\begin{array}{l}0,10 \\
1\end{array}$ & $-0,413$ & $-0,240$ & 0,157 & & \\
\hline & Unspecified & 2 & 0,653 & $\begin{array}{l}0,09 \\
9\end{array}$ & $6,599 * * *$ & 0,459 & 0,847 & & \\
\hline \multirow{3}{*}{$\begin{array}{l}\text { Level of } \\
\text { education }\end{array}$} & Primary & 18 & 0,020 & $\begin{array}{l}0,14 \\
0\end{array}$ & 0,141 & $-0,254$ & 0,294 & \multirow{3}{*}{1,145} & \multirow{3}{*}{2} \\
\hline & High School & 2 & 0,151 & $\begin{array}{l}0,21 \\
3\end{array}$ & 0,710 & $-0,266$ & 0,567 & & \\
\hline & $\begin{array}{l}\text { Higher } \\
\text { Education }\end{array}$ & 3 & $\begin{array}{l}- \\
0,302\end{array}$ & $\begin{array}{l}0,36 \\
7 \\
\end{array}$ & $-0,822$ & $-1,022$ & 0,418 & & \\
\hline \multirow{3}{*}{$\begin{array}{l}\text { Type of } \\
\text { publication }\end{array}$} & Article & 11 & $\begin{array}{l}- \\
0,090\end{array}$ & $\begin{array}{l}0,21 \\
1\end{array}$ & $-0,424$ & $-0,504$ & 0,325 & \multirow{3}{*}{0,321} & \multirow{3}{*}{2} \\
\hline & $\begin{array}{l}\text { Master } \\
\text { Thesis }\end{array}$ & 11 & 0,060 & $\begin{array}{l}0,17 \\
8\end{array}$ & 0,335 & $-0,289$ & 0,408 & & \\
\hline & $\begin{array}{l}\text { Doctoral } \\
\text { Thesis }\end{array}$ & 1 & 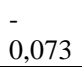 & $\begin{array}{l}0,39 \\
2\end{array}$ & $-0,185$ & $-0,840$ & 0,695 & & \\
\hline
\end{tabular}

When the results are analyzed, three moderating factors were defined as being thought to exert an important effect on the effect size $(p<.05)$. These were branch, level of education and type of publication. However, type of participant and publication were defined as being thought to exert no important effect on the effect size (p>.05). With regards to the influence of gender on inclusive education; (I) The studies included in meta-analysis have been found not to differentiate as regards to the type of participants. (II) The studies included in meta-analysis have been found to differentiate as regards to teachers or prospective teachers' branch. (III) The effect size calculated in the studies including teachers or prospective teachers in field of preschool teaching profession is significant and is in favor of women whereas the effect size calculated in the studies including teachers or prospective teachers is not significant. (IV) The studies included in meta-analysis have been found not to differentiate as regards to level of education. $(V)$ 
The studies included in meta-analysis have been found not to differentiate as regards to the type of publication.

On examining Table 5, one moderating factor-teachers or prospective teachers' branch was defined as being thought to exert an important effect on effect size $(\mathrm{p}<.05)$ whereas level of education, type of participant and publication were defined as being thought to exert no important effect on the effect size ( $>>.05)$. With regards to the influence of gender and special education training on attitudes towards inclusion; (I) The studies included in meta-analysis have been found not to differentiate as regards to type of participants. (II) The studies included in meta-analysis have been found to differentiate as regards to teachers or prospective teachers' branch. The effect size calculated in the studies with unspecified teaching professions is significant and in favor of participant with training whereas the effect size calculated in the studies with unspecified teaching professions is not significant. (III) The studies included in meta-analysis have been found not to differentiate as regards to the level of education. (IV) The studies included in meta-analysis have been found not to differentiate as regards to the type of publication.

\section{CONCLUSION}

In this study, there was an attempt to arrive at a synthesis of studies hitherto conducted on the subject of the effect of gender and special education training on attitudes towards inclusion. The research was conducted using a total of 51 studies that satisfied the stipulated criteria; 28 of which addressed the effects of the gender on the attitudes towards inclusive education and 23 that dealt with the effects of special education training on teachers' or prospective teachers' attitudes.

The average effect size was calculated according to the random effect model. The reason for this was the apparent heterogeneity (differentiation/variation) in the studies. On analysis of the results, it has been found that gender did not affect attitude towards inclusive education significantly $(Z=0,193, \mathrm{p}>.01)$ with a confidence interval of $95 \%$. The value of the average size effect was 0.034 and found to be positive. It has been found that special education training did not affect attitude towards inclusive education significantly $(Z=-0,125, p>.05)$ with a confidence interval of $95 \%)$. It has been determined that the value of the average size effect was $-0,016$ and found to be negative. The effect sizes were calculated as part of this research, which when arranged according to the principles of classification set out by Cohen at al., (2007) were found to be weak in nature.

When analysing the studies about the influence of gender on attitude, it has been found to be significant with a high effect and in favour of the female in Prakash (2012)'s study whereas it has been found to be significant with a high effect and in favour of the male in Chopra (2008) ve Murphy (2014)'s studies.

When analysing the studies about the influence of special education training on attitude, it has been found to be significant with a high effect and in favour of the participants with training in Chopra (2008)'s study whereas it has been found to be significant with a high effect and in favour of the participants with no training in Almotairi (2013) and Kalyva (2007)'s studies. 
The studies included within the scope of the research in terms of gender were found to be distributed around the upper and internal parts of the funnel plot. However, the studies included within the scope of the research in terms of special education training were found to be rarely distributed around the upper part of the graph. That is why these studies had little effect on the common effect. In summary, symmetry has not been observed in the studies included within the scope of the research in terms of both gender and special education training. Moreover, the studies that showed publication bias were also determined.

In the study, type of participant, branch, level of education and type of publication were defined as moderating factors. Branch was found to create a significant difference on gender and special education training.

According to the results of research, it is almost impossible to talk about clearly the positive or negative effect of gender and special education training on attitude towards special education. It became evident with calculation of the common effect size of the studies. Therefore, there is a need for the study of both gender and special education training. Inclusive education in the contemporary world is applied extensively in almost all the countries. The idea to bring the disabled students together at schools for the disables and train them in a different context by separating them from their peers has been replaced by the idea of greater integration. This can only occur in the setting with the inclusive education provided. Many countries have shut down the schools for teaching only students with disabilities and now work to integrate them with their peers in inclusive educational environments. When considered in this context, it would be appropriate to address this issue in detail and reach a saturation to decide in the field.

In addition, King and Edmunds (2001) in their study pointed out that decision-makers should take heed of the voices of teachers directly responsible for putting the inclusion into practice. Murphy (2014)'s review of the literature and her own research study have also reached the conclusion that the best way to improve teachers' attitudes towards inclusion is to give ear to teachers and to act on the needs they have expressed.

Gender is used as a variable in the comparatives tests in many studies. Actually, the research questions whether there is a significant difference in terms of gender have become fixed. However, this study has clearly showed that gender is not a variable creating a meaningful size effect. This result should be taken into account in the future studies.

Finally, a new meta-analysis study can also be done through printed papers, new published studies as well as thesis and articles.

\section{REFERENCES}

Avissar, G. (2000). Views of general education teachers about inclusion: An international perspective. Paper Presented at the International Education Congress, University of Manchester, London.

Avramidis at al., (2000). A survey into mainstream teachers' attitudes towards the inclusion of children with special education needs in the ordinary school in one local education authority. Educational Psychology; 20(2): 191-212. 
Avramidis, E., \& Norwich, B. (2002). Teachers' attitudes towards integration/inclusion: A review of the literature. European Journal of Special Needs Education, 17, 129- 147.

Babaoğlan, E. \& Yılmaz, Ş. (2010). "Sınıf Öğretmenlerinin Kaynaştırma Eğitimindeki Yeterlikleri”. Kastamonu Ĕgitim Dergisi. 18 (2), 345-354.

Batu, S. \& G, Kırcaali-İftar.(2011). Kaynaştırma. Ankara: KÖK Yayıncılık.

Bender at al., (1995). Teachers' attitudes toward increased mainstreaming Implementing effective instruction for students with learning disabilities. Journal of Learning Disabilities, 28(2), 87-94.

Borenstein at al., (2009). Introduction to meta-analysis. UK: John Wiley \& Sons Ltd.

Burke, K., \& Sutherland, C. (2004). Attitudes toward inclusion: Knowledge vs. experience. Education, 125(2), 163-172.

Cankaya, Ö. (2010). İlköğretim I. kademede kaynaştırma eğitimi uygulamalarının sınıf öğretmenlerinin görüşlerine göre değerlendirilmesi. Yayımlanmamış Yüksek Lisans Tezi, Selçuk Üniversitesi Eğitim Bilimleri Enstitüsü, Konya.

Cohen at al., (2007). Research methods in education (6. Edition). London: Routledge

Cooper at al., (2009). The handbook of research synthesis and meta-analysis (2. Edition). New York: Sage Publication.

Dickens-Smith, M. (1995) The Effect of Inclusion Training on Teacher Attitude towards Inclusion, ERIC Document No. ED 332802.

Dinçer, S. (2014). Eğitim bilimlerinde uygulamalı meta-analiz. Ankara: PegemA Yayıncılık.

Erkuş, A. (2013). Davranış bilimleri için bilimsel araştırma süreci (4. Baskı). Ankara: Seçkin Yayıncılık.

Gözün, Ö. \& Yıkmış, A. (2003). Öğretmen Adaylarının Kaynaştırma Konusunda Bilgilendirilmelerinin Kaynaştırmaya Yönelik Tutumlarının Değişimindeki Etkililiği. XIII. Özel Eğitim Kongre'sinde Sunulan Bildiri, Eskişehir.

Hedges, L. V. \& Olkin, I. (1985). Statistical methods for meta-analysis. USA: Academic Press Inc.

King, W. \& Edmunds, A. (2001). Teachers' perceived needs to become more effective inclusion practitioners: A single school study. Exceptionality Education Canada 11(1), 3-23.

Leyser, Y. \& Tappendorf, K. (2001). Are attitudes and practices regarding mainstreaming changing? A case of teachers in two rural school districts. Education, $121,751-760$.

Littell at al., (2008). Systematic reviews and meta-analysis. USA: Oxford University Press.

Martinez, R. (2003). Impact of a graduate class on attitudes toward inclusion, perceived teaching efficacy and knowledge about adapting instruction for children with disabilities in inclusive settings. Teacher Development, 7 (3), 473-494.

Orel at al., (2004). Sınıf Öğretmeni Adaylarının Kaynaştırmaya Yönelik Tutumlarının İncelenmesi. Ankara Üniversitesi Eğitim Bilimleri Fakültesi Özel Eğitim Dergisi, 5 (1): 23-33. 
Parasuram, K. (2006). Variables that affect teachers' attitudes towards disability and inclusive education in Mumbai, India. Disability \& Society, 21(3), 231-242.

Sarı, H. (2002). Özel egitime muhtaç ögrencilerin eğitimleriyle ilgili öneriler. Pegem A Yayınları, Ankara.

Sarı, H. \& Bozgeyikli, H. (2003) Öğretmen adaylarının özel eğitime yönelik tutumlarının incelenmesi: karşılaş̧ırmalı bir araştırma. Selçuk Üniversitesi Sosyal Bilimler Enstitüsü Dergisi, 9, 183-203.

Sharma et al., (2006). Pre-service teachers' attitudes, concerns and sentiments about inclusive education: An international comparison of the novice pre-service teacher. Manuscript submitted for publication.

Temel, Z. F. (2000). Okul öncesi Eğitimcilerinin Engellilerin Kaynaştırılmasına İlişkin Görüşleri, Hacettepe Üniversitesi Ĕ̈itim Fakültesi Dergisi 18: 148 - 155

UNESCO (2001) The Open File on Inclusive Education. Paris: UNESCO.

Üstün, U. \& Eryılmaz, A. (2014). Etkili araştırma sentezleri yapabilmek için bir araştırma yöntemi: meta-analiz. Ĕgitim ve Bilim, 39(174), 1-32.

\section{References Used in Meta-Analysis}

*Almotairi, M. (2013). Investigating Kuwaiti teachers' and head teachers' attitudes towards inclusion, Doctor of Philosophy, University: the UK.

*Alnahdi, G. H. (2012). Teachers' Attitudes and Perceptions Toward Transition Services from School to Work for Students with Mild Intellectual Disabilities in Saudi Arabia, Doctor of Philosophy, Ohio University: the USA.

*Alothman, A.A. (2009). Teachers' Attitudes Towards The Inclusion Of Students With Special Education Needs In Saudi Primary Schools.

*Alquraini, T. A. (2012). Factors related to teachers' attitudes towards the inclusive education of students with severe intellectual disabilities in Riyad. Journal of Research in Special Educational Needs, 12(3), 170-182.

**Alver at al., (2011). Psikolojik Danışma ve Rehberlik Programı Öğrencilerinin Kaynaştırma Eğitimine Yönelik Tutumlarının İncelenmesi. Atatürk Üniversitesi Sosyal Bilimler Enstitüsü Dergisi 201115 (1): 155-168.

*Avramidis, E., \& Norwich, B. (2002). Teachers' attitudes towards integration/inclusion: A review of the literature. European Journal of Special Needs Education, 17, 129- 147.

*Avramidis, E. \& Kalyva, E. (2007). The influence of teaching experience and professional development on Greek teachers' attitudes towards inclusion. European Journal of Special Needs Education, 22, (4), 367-389.

*Bilen, E. (2007). Sınıf Öğretmenlerinin Kaynaştırma Uygulamalarında Karşılaştıkları Sorunlarla İlgili Görüşleri Ve Çözüm Önerileri.Yayımlanmamış Yüksek Lisans Tezi, Dokuz Eylül Üniversitesi Eğitim Bilimleri Enstitüsü, İzmir.

**Bek at al., 2009).Sınıf Öğretmeni Adaylarının kaynaştırma Eğitimine Yönelik Tutumlarının incelenmesi. Uşak Üniversitesi Sosyal Bilimler Dergisi (2009) 2/2, 160-168.

*Boyle at al., (2013). Teachers' Attitudes Towards Inclusion In High Schools. Teachers and Teaching: Theory and Practice, 19, (5), 527-542.

**Cagney, T.L. (2009) Attitudes of general education teachers toward including students with special needs, Master Of Science, Iowa State University: the USA. 
*Cankaya, Ö. (2010). İlköğretim I. Kademede Kaynaştırma Eğitimi Uygulamalarının Sınıf Öğretmenlerinin Görüşlerine Göre Değerlendirilmesi. Yayımlanmamış Yüksek Lisans Tezi, Selçuk Üniversitesi Eğitim Bilimleri Enstitüsü, Konya.

*Chopra, R (2008). Factors Influencing Elementary School Teachers' Attitude Towards Inclusive Education. Education Line, Paper presented at the British Educational Research Association Annual Conference, Heriot-Watt University, Edinburgh, the UK.

**Çolak, M. \& Çetin, M.(2014). Öğretmenlerin Engelliliğe Yönelik Tutumları Üzerine Bir Araştırma. Dokuz Eylül Üniversitesi İktisadi ve İdari Bilimler Fakültesi Dergisi Cilt:29, Sayı:1, Y11:2014, ss. 191-211.

*Dağlar, G.(2011). Okulöncesi Öğretmenlerinin Ve Okulöncesi Öğretmen Adaylarının Kaynaştırmaya İliş̧in Görüşlerinin Karşılaştırılması. Yayımlanmamış Yüksek Lisans Tezi, Mehmet Akif Üniversitesi Sosyal Bilimler Enstitüsü, Burdur.

*Doulkeridou at al., (2011). Attitudes Of Greek Physical Education Teachers' Towards Inclusion Of Students With Disabiliries In Physical Education Classes. International Journal Of Special Education, 26 (1).

*Dukmak, S.J. (2013). Regular Classroom Teachers' Attitudes towards Including Students with Disabilities in the Regular Classroom in the United Arab Emirates. The Journal of Human Resource and Adult Learning, 26, 9, (1).

*Ekşi, K.(2010). Sınıf Öğretmenleri İle Özel Eğitim Öğretmenlerinin Kaynaştırma Eğitimi İle İlgili Tutumlarının Karşılaştııılması. Yayımlanmamış Yüksek Lisans Tezi, Marmara Üniversitesi Eğitim Bilimleri Enstitüsü, İstanbul.

*Fakolade at al., (2009) Attitude of teachers towards the inclusion of special needs children in general education classroom: the case of teachers in some selected schools in Nigeria. International Electronic Journal of Elementary Education 1, (3).

*Gökdere, M. (2012). Sınıf Öğretmenleri ile Sınıf Öğretmeni Adaylarının Kaynaştırma Eğitimine Yönelik Tutum, Endişe ve Etkileşim Düzeylerinin Karşılaştırmalı İncelemesi. Kuram ve Uygulamada Eğitim Bilimleri • Educational Sciences: Theory \& Practice - 12(4) • Güz/Autumn • 2789-2806.

*Güleryüz, B. (2014). Sınıf Öğretmenlerinin Ve Sınıf Öğretmeni Adaylarının Kaynaştırma Eğitimine İlişkin Görüşlerinin Belirlenmesi. Yayımlanmamış Yüksek Lisans Tezi, Bülent Ecevit Üniversitesi Sosyal Bilimler Enstitüsü, Zonguldak.

*Haimour, A.I. \& Obaidat, Y.F, (2013). School Teachers' Attitudes Toward Inclusion Of Students With Autism In Saudı Arabia. International Journal of Current Research Department of Special Education, King Abdulaziz University, Saudi Arabia 5 (10), 2970-2977.

*Kalyva at al., (2007). Serbian Teachers' Attitudes Towards Inclusion. International Journal Of Special Education, 22 (3).

*Karacaoğlu, İ. (2008). İlköğretim Okullarında Görev Yapmakta Olan Öğretmenlerin Okul İklimi Algıları İle Kaynaştırmaya İlişšin Tutumları Arasındaki İlişkinin İncelenmesi. Yayımlanmamış Yüksek Lisans Tezi, Yeditepe Üniversitesi Sosyal Bilimler Enstitüsü, İstanbul.

*Kern, E. (2006). A Survey of Teacher Attitude Regarding Inclusive Education Within an Urban School District, Doctor of Philosophy, Philadelphia College of Osteopathic Medicine Department of Psychology: the USA.

*Kışla, T. (2008). Özel Eğitim Öğretmenlerinin Bilgisayar Tutumlarının İncelenmesi. Ege Eğitim Dergisi 2008 (9) 2: 128-154. 
*Kiriungi at al., (2014). An Assessment of Public Primary School Teachers' Attitude towards Inclusion of Children with Hearing Impairment in Central Region of Kenya. International Journal of Education and Research, 2 (3).

*Kuzu, S. (2011). Öğretmen Adaylarının Kaynaştırma Eğitimine Yönelik Tutumları Ve Öz Duyarlık Düzeylerinin Karşıllaştııılması. Yayımlanmamış Yüksek Lisans Tezi, Marmara Üniversitesi Eğitim Bilimleri Enstitüsü, İstanbul.

*Mukhopadhyay, S. (2014). Botswana primary schools teachers' perception of inclusion of learners with special educational needs. Journal of Research in Special Educational Needs, 14(1), $33-42$.

**Murphy, K. (2014). Teacher Attitudes Toward Inclusion Practices University of Botswana. Master of Science, Mount Saint Vincent University: Scotland.

*Onur, M. (2009). Rehber Öğretmenlerin Kaynaştırma Eğitimine Yönelik Tutumlarının Değerlendirilmesi (Kâğıthane İlçesi Örneği).Yayımlanmamış Yüksek Lisans Tezi, Beykent Üniversitesi Sosyal Bilimler Enstitüsü, İstanbul.

*Özdemir, H. (2010).Okul Öncesi Öğretmenlerinin Kaynaştırma Uygulamasına İlişkin Görüşlerinin İncelenmesi. Yayımlanmamış Yüksek Lisans Tezi, Trakya Üniversitesi Sosyal Bilimler Enstitüsü, Edirne.

*Prakash, S.S. (2012). Inclusion of Children with Hearing Impairment in Schools: A Survey on Teachers' Attitudes, Disability, CBR \& Inclusive Development, 23(3).

**Seçer, F.(2011). Sınıf Öğretmenlerinin Kişiler Arası Özyeterlik İnançları İle Kaynaştırmaya Yönelik Tutumlarının Çeşitli Değişkenler Açısından İncelenmesi. Yayımlanmamış Yüksek Lisans Tezi, Selçuk Üniversitesi Eğitim Bilimleri Enstitüsü, Konya.

*Subban ve Sharma, (2006). Primary School Teachers' Perceptions Of Inclusive Education In Victoria. International Journal Of Special Education, 21 (1).

*Şahin, F. \& Güldenoğlu, B. (2013). Engelliler Konusunda Verilen Eğitim Programının Engellilere Yönelik Tutumlar Üzerindeki Etkisi. Amasya Üniversitesi Eğitim Fakültesi Dergisi 2(1), 214-239.

*Tekneci, E. (2010). Zihin Engelliler Öğretmenliği 1. ve 4. Sınıf Öğrencilerinin Öğretmenlik Mesleğine Yönelik Tutumları İle Kaygı Düzeylerinin Karşılaştırılması. Yayımlanmamış Yüksek Lisans Tezi, Marmara Üniversitesi Eğitim Bilimleri Enstitüsü, İstanbul.

*Yiğiter, S. (2005). Sınıf Öğretmenlerinin Özel Öğrenme Güçlüğüne İlişkin Bilgi Düzeyleri ile Özel Öğrenme Güçlüğü Olan Çocukların Kaynaştırılmasına Yönelik Tutumları Arasındaki İlişkinin İncelenmesi. Yayımlanmamış Yüksek Lisans Tezi, Marmara Üniversitesi Eğitim Bilimleri Enstitüsü, İstanbul.

*Wilson, V.A., (2014). Secondary General Education Teachers' Attitudes Toward Inclusion. Doctor of Philosophy, Regent University: the USA.

*Zağlı, Ü. (2011). Sakarya İlinde Görev Yapan Okul Öncesi Öğretmenlerin Zihinsel Engelli Çocukların Kaynaştırma Yoluyla Eğitimlerine İlişkin Tutumlarının İncelenmesi. Yayımlanmamış Yüksek Lisans Tezi, Gazi Üniversitesi Eğitim Bilimleri Enstitüsü, Ankara.

** The references marked with two asteriks $(* *)$ are the ones used both in meta-analysis studies and references. 


\section{Turkish Abstract}

\section{Kaynaştırmaya Karşı Tutum Üzerinde Cinsiyet ve Özel Öğretim}

Özel eğitimde kaynaştırma eğitimi uygulamaları oldukça önemlidir ve olduça çok tartışılmıştır. $\mathrm{Bu}$ bağlamda, öğretmenlerin kaynaştırma eğitimi ugulamalarına olan bakışları ve tutumları oldukça önemlidir. Literatürde özel eğitim uygulamalarına ilişkin olukça çok yayın bulunmaktadır. $\mathrm{Bu}$ makalede özel eğitimde kaynaştırma eğitimi uygulamalarına odaklanmış ve özel eğitime karşı öğretmen tutumlarına ilişkin çalışmaların bulguları sentezlenmiştir. Kaynaştırma eğitimi uygulamalarına karş öğretmen tutumları cinsiyet ve özel eğitim öğrenimi açısından incelenmiştir. Cinsiyetin etkisi bağlamında kriterlere uyan 28 çalıșma bulunurken, özel eğitim öğrenimi bağlamında dahil etme kriterlerine uyan 23 çalışma bulunmaktadır. Çalışmanın bulguları cinsiyetin ve özel eğitim öğreniminin kaynaştırmaya karşı olan tutumu anlamlı derecede etkilemediğini göstermiştir. Çalışmada gözlemlenen moderator faktörlerden sadece öğretmenlerin branşı anlamlı çıkmıştır.

Anahtar Kelimeler: kaynaştırma, tutum, meta-analiz, cinsiyet, öğrenim, özel eğitim

\section{French Abstract}

L'Influence de Genre et Enseignement spécialisé Recevant une formation sur Attitudes vers Inclusion

Des pratiques d'enseignement incluses sur l'enseignement spécialisé sont tout à fait importantes et discutées intensivement. Dans ce contexte, les points de vue des professeurs et des attitudes vers des pratiques d'enseignement incluses sont très importants. Il y a beaucoup de publications de pratiques d'enseignement spécialisé dans l'examen de littérature. Dans cet article, il a été concentré sur des pratiques d'éducation incluses dans l'enseignement spécialisé et la synthèse des conclusions d'études examinant les attitudes des professeurs vers l'enseignement spécialisé. Les attitudes des Professeurs vers les pratiques d'éducation incluses ont été examinées en termes de la formation d'enseignement spécialisé et genre. Il y a 28 études qui ont respecté les critères inscrits incluant l'échantillon de l'influence du genre sur les attitudes vers l'enseignement inclus et 23 études respectant les critères d'inclusion incluant l'échantillon de l'influence d'enseignement spécialisé recevant une formation sur les attitudes des professeurs ou professeurs éventuels. Les découvertes de l'étude ont indiqué que le genre et la formation d'enseignement spécialisé n'ont pas affecté les attitudes vers l'enseignement inclus significativement. Des facteurs se modérant observés dans l'étude, seulement on a vu que les différences des branches des professeurs ont été de signification.

Mots Clés: inclusion, attitude, meta-analyse, genre, formation, enseignement specialise

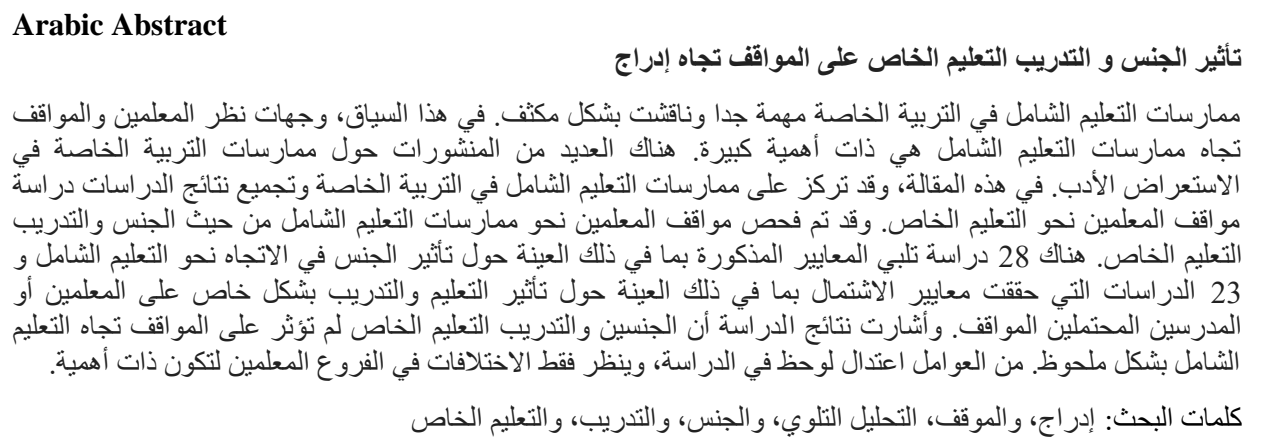




\section{German Abstract \\ Der Einfluss von Geschlecht und Sonderpädagogik Ausbildung auf Einstellungen zur Inklusion}

Inklusive Bildung Praktiken in Sonderschulen sind sehr wichtig und intensiv diskutiert. In diesem Zusammenhang Lehrersichtweisen und Einstellungen gegenüber der inklusiven Bildung Praktiken sind von großer Bedeutung. Es gibt viele Publikationen über spezielle Bildungspraktiken in der Literaturrecherche. In diesem Artikel hat es auf inklusive Bildung Praktiken in der Sonderpädagogik und Synthese der Ergebnisse von Studien untersuchen Lehrer Einstellungen gegenüber spezielle Ausbildung konzentriert. Lehrer Haltung gegenüber der inklusiven Bildung Praktiken wurden im Hinblick auf Geschlecht und spezielle Ausbildung Schulung untersucht. Es gibt 28 Studien, die die Kriterien erfüllt aufgelistet, einschließlich der Probe über den Einfluss des Geschlechts auf die Einstellung gegenüber der inklusiven Bildung und 23 Studien, welche den Einschlusskriterien einschließlich der Probe über den Einfluss von Sonderschulausbildung auf die Einstellung von Lehrern oder angehende Lehrer. Die Ergebnisse der Studie zeigten, dass Geschlecht und spezielle Ausbildung Schulung nicht die Haltung gegenüber der inklusiven Bildung wesentlich beeinflusste. Von den moderierenden Faktoren in der Studie beobachtet wurden nur die Unterschiede in den Filialen der Lehrer gesehen von Bedeutung zu sein.

Schlüsselwörter: inklusion, haltung, meta-analyse, geschlecht, ausbildung, sonderpädagogik

\section{Malaysian Abstract}

Pengaruh Jantina dan Latihan Pendidikan Khas Insklusif Ke Atas Sikap Terhadap Kemasukan

Amalan pendidikan inklusif pendidikan khas yang agak penting dan perlu dibincangkan secara intensif. Dalam konteks ini, pandangan dan sikap guru terhadap amalan pendidikan inklusif adalah sangat penting. Terdapat banyak penerbitan mengenai amalan pendidikan khas dalam kajian literatur. Dalam artikel ini, ia telah memberi tumpuan kepada amalan pendidikan inklusif dalam pendidikan khas dan mensintesis hasil kajian dengan memeriksa sikap guru terhadap pendidikan khas. Sikap guru terhadap amalan pendidikan inklusif telah dikaji dari segi jantina dan latihan pendidikan khas. Terdapat 28 kajian yang memenuhi kriteria yang disenaraikan termasuk sampel mengenai pengaruh jantina pada sikap terhadap pendidikan inklusif dan 23 kajian memenuhi kriteria kemasukan termasuk sampel mengenai pengaruh latihan pendidikan khas pada sikap guru atau bakal guru. Dapatan kajian menunjukkan bahawa jantina dan latihan pendidikan khas tidak menjejaskan sikap terhadap pendidikan inklusif dengan ketara. Satu faktor yang sederhana diperhatikan dalam kajian ini, hanya perbezaan di cabang-guru dilihat menjadi amat penting.

Kata Kunci: inklusif, sikap, meta-analisis, jantina, latihan, pendidikan khas 